\title{
Britain must tackle 'genetic illiteracy' among new doctors
}

London. Britain needs to increase substantially its support for the clinical applications of genetics if it is to make proper use of the information emerging from the Human Genome Programme (HGP), according to the head of one of the country's largest genetics services.

Speaking at a conference in London last week on science and medicine organized by the Department of Health, Pat Jacobs, of the Wessex Regional Genetics Laboratory in Salisbury, added that there was also an urgent need to boost the training of medical students in genetics-related issues, complaining that many doctors were coming out of medical schools "genetically illiterate".

Jacobs pointed out that, five years ago, a report from the Royal College of Physicians (RCP) had claimed clinical genetics services in Britain were on average 60 per cent understaffed. Since then, new genetic knowledge and screening techniques had doubled the work-load on such services, but with no comparable increase in funding.

"To bring it up even to the minimal level recommended in 1990, our regional authority would need to spend another quarter of a million pounds a year, and if Wessex is typical, this means spending about $£ 4$ million (US\$6.4 million) on England and Wales as a whole," said Jacobs. "This is a large sum, but it is not overwhelming, particularly when you compare it to the sums spent on the HGP itself."

Jacobs said there was "little point" spending vast sums of money on the genome project if the information it produces cannot be translated into health care because of inadequate educational and clinical resources. In particular, there was a "very urgent need" to bring staffing levels of the clinical genetics services in Britain up to the minimum level described in the RCP report.

Financial support for clinical genetics services should grow at a rate commensurate with the enormous increase in their work-load. This has resulted not only from the need to provide screening and other services directly, but also from fulfilling the huge educational role - for both the public and for medical practitioners - that has been placed on their shoulders.

"People assume that medical schools provide an excellent genetics education for the next generation of doctors," said Jacobs. "Unfortunately, this is far from true; few medical schools incorporate genetics teaching throughout the curriculum... As a result, we are going to have another generation of doctors who will be unable to cope with the so-called genetics revolution, and this also needs to be addressed urgently."

David Dickson

\section{France asked to supply more data on $\mathbf{N}$-test monitoring}

Paris. The European Commission is expected formally to ask France this week to supply it with sufficient information to verify that the precautions being taken by France at its nuclear test sites at Mururoa and Fangataufa in the South Pacific are sufficient to safeguard public health.

The move follows a decision by France to deny access to some facilities to an inspection team sent by the commission to French Polynesia earlier this month. At a meeting scheduled to be held this week, the commission will establish what data it lacks, and request France to provide it.

France has accepted that the commission has the power to demand such data, and to verify control facilities, under articles of the Euratom treaty of 1957, which allows the commission to ensure that control measures taken by member states to keep radioactive emissions within certain limits are sufficient. In July, France submitted a detailed technical report to the commission on the control measures being taken in the South Pacific.

But the commission says it needs further information. Furthermore, if it decides that the tests are 'particularly dangerous', then the commission could require France to take extra control measures, under a separate article of the Euratom treaty. The French government, however, has refused to accept the commission's competence to implement this article, on the grounds that the Euratom treaty applies only to civil, and not military, nuclear installations.

Indeed, the latter restriction means that, while the commission could eventually make public its judgement on any risks posed by the French tests, the treaty provides no mechanism by which it could require the tests to be halted.

Similarly, while the commission says it "has the option" of taking France to the European Court of Justice for infringing the treaty, should France refuse to supply all the data that the commission is scheduled to request this week, the court has no power to stop the tests. "We couldn't formally condemn France, as the tests are a military issue," says one commission official.

"The reality of the situation is that France will do whatever it wants to do", says the official. Earlier this month, for example, the commission requested France to supply it with additional data before carrying out its second nuclear test. In what could be interpreted as a diplomatic reminder to the commission of its limited powers, France proceeded with a 110-kilotonne test at Fangataufa.

Declan Butler

\section{German states seek funding balance}

Munich. In a bid to reduce regional inequalities, research ministers from the federal government and Germany's 16 Länder have proposed for the first time a change in the formula that determines how much an individual Land has to contribute to the support of a research institute in its territory.

According to the so-called Königstein Schlüssel formula, set up as part of German post-war reconstruction, the Max Planck and 'Blue List' research institutes each receive half of their funding from the federal government. The rest is shared between Länder, under a mechanism that has come under strain with the absorption of research institutes from the former East Germany.

At present, the host Land pays 25 per cent of the Länder share of the costs of Max Planck institutes, the remainder coming from a shared pot to which all Länder contribute. This limits the political influence of the host Land over the institutes. But it also places a heavy financial burden on Länder with few such institutes.

By contrast, the host Land bears the full Länder share of the Blue List research institutes. Before reunification these were relatively few. After reunification, however, the number of Blue List institutes rose from 48 to 82 , with the inclusion of many institutes of the former East German Academy of Sciences. Concern over the relative weakness of quality control mechanisms has increased, while the new Länder in the east have been quick to complain of the financial burden.

The research ministers have now proposed, through the Bund-Land Kommission (BLK), which brokers agreements between federal and Länder governments, that the host Land should pay 75 per cent of the Länder share of the costs of its Blue List institutes. The remaining 25 per cent would come from a common pot, set up through the newly created Blue List umbrella group (AG-BL), which will arrange a formal system of evaluation of the institutes. The BLK also suggests that the host Land share of funding for Max Planck institutes should rise from 25 to 50 per cent.

The proposals require the approval of the finance ministers and prime ministers of all the Länder. Opposition is expected from Länder such as Thüringen, with relatively few Blue List institutes, which would still contribute the same as other regions to the central pot. This makes it unlikely that new financing mechanisms will be introduced in 1997, as the BLK suggests. Alison Abbott 